\title{
Empirical Study on the Impact of Social Responsibility Information Disclosure on Corporate Equity Capital Cost*
}

\author{
Xuexin Liu \\ School of Business Administration \\ Capital University of Economics and Business \\ Beijing, China 100070
}

\author{
Xiaoxu Kong** \\ School of Business Administration \\ Capital University of Economics and Business \\ Beijing, China 100070 \\ **Corresponding Author
}

\author{
Mengyu Sun \\ School of Business Administration \\ Capital University of Economics and Business \\ Beijing, China 100070
}

\begin{abstract}
The paper mainly discusses the impact of corporate social responsibility information disclosure on the cost of equity capital. Based on the theory of signal transmission and the theory of legality, the mechanism of action was analyzed. The listed companies that issued the social responsibility report in 2013-2015 were selected for empirical research. The empirical results show that corporate social responsibility information disclosure has a significant negative impact on the cost of equity capital.
\end{abstract}

Keywords-corporate social responsibility information disclosure; the cost of equity capital; signal transmission theory; legitimacy theory

\section{INTRODUCTION}

With the development of economic globalization, unlike the simple pursuit of "profit maximization" in the past, modern enterprises have become a new development goal by establishing a good image and enhancing competitiveness by fulfilling social responsibilities. Competition among enterprises is not only manifested in the competition of products and services in the market, but is gradually evolving into a comprehensive competition that includes social responsibility. Under the vigorous promotion of China's Shanghai and Shenzhen Stock Exchanges and the Stateowned Assets Supervision and Administration Commission, a series of related documents have been issued, encouraging enterprises to actively fulfill their social responsibilities and

*[Fund Project] The project commissioned by the Ministry of Ecology and Environment of the People's Republic of China, "Study on the short-term effects of environmental protection inspectors on the Chinese economy."

Fund Project: The National Social Science Fund General Project "Research on the Governance Structure Model and Operation Mechanism of Public Welfare Institutions" (Approval No. 13BGL121); Support plan of construction of high-level teachers in colleges and universities in Beijing,

"High-level innovation team building plan". actively reveal social responsibility information ${ }^{1}$. Enterprises are also increasingly revealing social responsibility information through diversified channels, including the company's annual report, independent social responsibility report, and the company's official website (official media). In recent years, the number of companies that publish social responsibility reports has increased. In 2016, 747 listed companies in the Shanghai and Shenzhen Stock Exchanges revealed their annual corporate social responsibility reports, compared with 701 in 2015 and 681 in 2014

In recent years, the academic community has paid more and more attention to the research in the field of social responsibility information disclosure. However, due to the late start, the research content has not yet established a complete system. At present, there are at least three conclusions of positive, negative and irrelevant. But Most scholars have affirmed the value of social responsibility information disclosure. Anderson and Frankle (1980) pointed out that the risk assessment of the company's stock portfolio by the capital market can be reduced by conducting full disclosure of social responsibility information [1]. Cornell and Shapiro (1987) argue that corporate disclosure of social responsibility information can reduce future risks and uncertainties in the capital market, allowing investors to obtain more useful

"Guiding Opinions on the Implementation of Socia Responsibilities of Central Enterprises"; in May 2008, the Shanghai Stock Exchange issued the "Guidelines for Environmental Information Disclosure of Listed Companies on the Shanghai Stock Exchange"; in January 2009, the Shanghai Stock Exchange issued the "Guidelines for the Preparation and Review of Internal Control Reports and Social Responsibility Reports of Listed Companies"; in November 2009, the State-owned Assets Supervision and Administration Commission issued the "Notice on Strengthening the Relevant Matters Concerning the Management of Foreign Donations of Central Enterprises"; in April 2010, the Ministry of Finance issued the "Guidelines for the Application of Internal Control of Enterprises No. 4 Social Responsibility”. 
information to dispel concerns and avoid high requirements of return due to increased risk premiums [2]. Robinson (2013) also believes that companies with poor social responsibility performance will increase investors' assessment of their risks and may lead to uncertain claims in the future. However, it is possible to reduce the investor's uncertainty about future risks through high-quality descriptions of performance on responsibilities, thereby reducing the necessary rate of return for investment [3]. Some domestic scholars also use the data of Chinese listed companies to conduct empirical research. Zeng Ying and Lu Zhengfei (2006) used the residual income model to calculate the cost of equity financing, and found a negative relationship between the two through step-by-step multiple regression, that is, high-quality information disclosure can bring positive capital cost effects [4]. Yang Qiulin and Dai Jinyun (2011) used 109 listed companies in Shanghai and Shenzhen as samples, and found through empirical research that social responsibility information disclosure can significantly reduce the risk of stocks, improve the liquidity of stocks, and reduce the cost of equity capital through these two channels[5]. Li Wei, Zhao Ying and Tong Jing (2013) believe that corporate disclosure of social responsibility reports can help to convey positive information, obtain support from various information users, attract more investors, and reduce the cost of equity capital. And there is the "first disclosure" effect [6]. Li Huiyun et al. (2016) found that voluntary information disclosure (including corporate social responsibility information disclosure) was significantly negatively correlated with the cost of equity capital, and this effect was more pronounced in areas with higher degree of marketization [7]. Huang Jianyuan and Jin Yue (2016) found that enterprises with better social responsibility performance in China's A-share listed companies can enjoy lower equity capital costs, that is, there is a negative correlation between the two, and independent social responsibility reports can achieve the transmission of social responsibility information, so that investors get effective information, further strengthens the above negative correlation [8].

However, some scholars have found that the cost of equity capital does not fall but increase after the company discloses social responsibility information. For example, Welker (2001) conducted an empirical study of 322 listed companies in Canada and found that disclosure of social responsibility information significantly increased financing costs. However, this positive impact will be somewhat weakened by the securities returns brought about by social responsibility information disclosure [9]. Some scholars believe that there is no simple linear relationship between the two, but a U-shaped relationship. Meng Xiaojun et al (2010) believe that a certain degree of social responsibility information disclosure can increase the transparency of information, thereby reducing the cost of capital, but once over-disclosed, it will increase the risk assessment of investors and increase the cost of equity capital [10].

Summarizing the existing research, we can find that scholars have already paid attention to the impact of corporate social responsibility information disclosure on the cost of corporate equity capital. However, due to differences in sample selection and research methods, no consistent research conclusions have been obtained. Therefore, it is not conducive to the company to correctly realize the value that social responsibility can fulfill and disclose, which leads to the neglect of social responsibility issues. Moreover, the number of empirical research results on the cost-effectiveness of equity capital in China is small and needs to be further improved.

This paper plans to analyze the logical mechanism of social responsibility information disclosure affecting the cost of corporate equity capital based on the theory of signal transmission and the theory of legality, further empirical research was conducted on the data of the disclosure of social responsibility reports of listed companies in Shanghai and Shenzhen. The research in this paper will help enterprises to improve their sense of responsibility while conducting better disclosure of social responsibility information, maintaining good communication with stakeholders, and achieving sustainable development of enterprises. And it will also help government departments to fully realize the importance of improving the quality of corporate information disclosure, thereby further improving the relevant legal system, and helping other stakeholders to better obtain social responsibility information that is highly relevant to their own interests and improve the effectiveness of decision-making.

\section{THE LOGICAL MECHANISM OF SOCIAL RESPONSIBILITY INFORMATION DISCLOSURE AFFECTING THE COST OF CORPORATE EQUITY CAPITAL}

\section{A. Analysis Based on the Theory of Signal Transmission}

Why does the application of the theory of signal transmission could explain that companies can have certain effects on social responsibility information disclosure? When there is a motivation for signal transmission, it is often beneficial for enterprises to improve information transparency and achieve effective information transmission. According to the principle of information transmission, when information is not disclosed in time, investors often regard it as bad news. Therefore, high-quality companies often have higher willingness to disclose and more timely disclosure to transmit good signals to the market, while companies with poor performance are difficult to imitate such behavior. Therefore, social responsibility information disclosure is often considered a common practice for high-quality companies. Myers and Majluf (2001) believe that managers have more information about the prospects of business development than outsiders. If there is information asymmetry, it will greatly increase the financing cost. Therefore, management will consciously strengthen information communication with external investors and actively disclose information about the company's financial status, future prospects and social responsibility performance, which will help increase corporate information transparency and reduce financing costs [11].

According to the theory of signal transmission, when there is information asymmetry between the two parties in the capital market, the judgment of the information inferior party is largely influenced by the relevant signals transmitted by the party with the information superiority. Therefore, enterprises can transmit "signals" about the development of enterprises and their attitudes towards responsibility through good social 
responsibility information disclosure. In order to attract investors' attention and reduce the cost of capital, it can distinguish it from other undisclosed companies. Many classic literatures also examine the relationship between information disclosure levels and capital costs. Copeland and Galai (1983), Diamond, and Verrcchia (1991) argue that by disclosing more information companies can increase stock liquidity and demand, and reduce transactions, achieving lower capital costs [12] [13].

\section{B. Analysis Based on the Legitimacy Theory}

Suchman (1995) gives the definition of legitimacy on the basis of comprehensive predecessors' research. He believes that legitimacy is a cultural process, and the behavior of entities should be within the norms, values, beliefs and definitions of certain social construction, so it could be recognized and accepted. At the same time, the legitimacy theory is divided into the institutional view and the strategic view. The institutional view believes that the organization only passively adapts to the static institutional environment. The strategic view is that even if the company does not change the actual behavior, it can change the social cognition through active communication and so on [14]. Legitimacy does not refer to the value judgments an individual makes on organizational behavior. Rather, it emphasizes the extent to which social groups as a whole accept or support the organization. Legitimacy is closely related to the social value of the organization and the various resources available to society. Clarke (2010) believes that organizations should not only follow and maintain legitimacy, but should also make timely compensation when it finds that the legitimacy is missing [15]. Therefore, in order to enable the society to recognize and accept, and to obtain the resources needed to achieve its goals, the company will show a behavior that conforms to legitimacy. And through active or passive information disclosure, demonstrate its acceptance of social culture, and the follow and maintaining of the norms.

In the interaction process between organizational and social, there may be a legitimacy gap. Deegan (1999) argues that social responsibility reporting can be used as a tool to deal with social normative changes and legitimacy management [16]. Mathews (1995) pointed out that society has diverse evaluation criteria for the legitimacy of different organizations' behaviors. Some resource-based and environmental organizations have stronger reliance on politics and society, and therefore will face more stringent social responsibility standards[17]. Guthrie et al. (1989) argue that the theory of legality explains that companies will disclose their own responses to changes in the social environment and use this form of information disclosure to demonstrate the legitimacy of their actions [18]. Dowling (1975) believes that there are two modes to improve legitimacy: one is to make corporate goals, product services, behaviors, etc. conform to social norms and norms; the other is to change the legal definition of society by means of information communication, thus gradually accept the company's current behavior, values, etc. [19]. It can be seen that the corporate social responsibility information disclosure conforms to the concept of legality theory, that is, through positive disclosure behaviors to change society's perception of it, thereby reducing the cost of equity capital.

\section{RESEARCH AND DESIGN}

\section{A. Models and Variables}

1) Empirical model: Considering the potential endogeneity of the model and enhancing the reliability of the conclusion, the score of social responsibility disclosure level is taken from one phase lagging data, and the following empirical model is constructed:

$\mathrm{COEt}=\beta 0+\beta 1$ Scoret$1+\beta 2$ Sizet $+\beta 3$ Statet $+\beta 4$ Firstt $+\beta 5$ ROAt $+\beta 6$ Turnt $+\beta$ 7Turnovert $+\varepsilon$

\section{2) Definition of variables}

a) Measurement of corporate social responsibility information disclosure level: At present, the academic community has proposed a variety of measurement methods, which are mainly divided into social responsibility accounting method, content analysis method and index method (Li Zheng, Xiang Rui, 2007) [11]. Accounting method refers to the measurement of various social responsibility information disclosed by accounting methods, and divides the accounting subjects affected by social responsibility-related activities into four categories: social assets, social liabilities, social benefits and social costs. However, due to the diversification of the four categories of standards, the comparability and credibility of data between different companies is greatly reduced [20]. The content analysis method refers to the analysis and statistics of the documents published in the company's externally published documents or social responsibility reports, and determines the assignment and weight of each specific item through the total number of pages, word count or content analysis, and then constructs social responsibility information disclosure indicators, but there is strong subjectivity. The index method first classifies the social responsibility information disclosed by the company, then subdivides the large categories into multiple small categories, and conducts qualitative and quantitative analysis for each small category to obtain assignments and scores. Finally, the total score is used to represent the overall level of social responsibility information disclosure [21].

By summarizing these methods and combining with China's situation, this paper intends to draw on the research of Tao Wenjie and Jin Zhanming (2013), Li Shu (2013), Zhang Zhengyong (2015), etc., using the RKS MCT Social Responsibility Report Rating Database to conduct research. The score of Rankins CSR Ratings is selected as the measurement index. The larger the indicator, the higher the level of corporate social responsibility disclosure $[6]^{2}$.

The latest version of RKS evaluation system is MCT 2012_1.2i. The system refers to the international authoritative social responsibility standard ISO26000 and sets four zero-level indicators, namely Macorocosm Technical, Content and Industry. On this basis, fifteen first-level indicators such as "governance", "stakeholders", "environment", "community participation and development", and sixty-three second-level indicators (excluding industry indicators) were established). The report is comprehensively evaluated and the indicators are implemented to the specific 
b) Measurement of corporate equity capital cost: The explanatory variable in this paper is the cost of equity capital. At present, the academic community's measurement of the cost of equity capital mainly has two measures of ex ante and ex post. Studies have shown that the assumptions of postevent capital costs in the actual capital market are often difficult to satisfy. Therefore, a large number of scholars adopt the measurement method of ex ante capital cost. Mao Xinshu et al. (2012) examined the effectiveness of different equity capital measurement and found that the PEG model and MPEG model are more in line with the current situation of China's capital market, and more appropriately capture the impact of various risk factors than other measurement methods [22]. Therefore, this paper uses the PEG model to measure the cost of equity capital. The formula of the model is as follows:

$$
\mathrm{COE}=\sqrt{\frac{(\mathrm{EPS} 2-\mathrm{EPS} 1)}{\mathrm{P} 0}}
$$

In the above formula, $\mathrm{P} 0$ is the base price per share, and EPS represents the analyst's forecasted earnings per share.

c) Selection and measurement of control variables: Drawing on the existing achievements of domestic and foreign scholars on corporate social responsibility and equity capital costs, it is planed is determine the size of the company, the nature of the equity, the shareholding ratio of the largest shareholder, sustainable growth rate, total net profit margin, asset-liability ratio, total asset turnover, operating leverage, stock turnover, and number of years of listing as control variables. Reasonable control variables will be selected based on different model needs. The symbols and definitions of specific variables are shown in "Table I".

\section{B. Sample Selection and Data Source}

The A-share listed company that released the social responsibility report in China from 2013 to 2015 is the research object. It should be pointed out that usually the CSR report will be disclosed at the beginning of the following year. For example, the social responsibility in 2013 is actually disclosed in 2014. The year referred to in this article is the year of the social responsibility report, not the release year. To ensure the reliability of the empirical results, the sample was processed as follows: (1) Excluding ST listed companies (2) Excluding financial and insurance listed companies (3) Excluding companies that have not made continuous disclosures during the research year (4) Excluding companies with missing key financial indicators, and then get 545 final data of sample companies for 3 years.

The relevant data of social responsibility disclosure in this paper comes from RKS database; financial data and corporate governance data are mainly from CSMAR and CCER databases; in this paper, Stata 14.0 and Excel are used as statistical analysis software. At the same time, in order to control the influence of extreme values on the regression results, the continuous variables involved in the model are subjected to Winsorize tailing processing at a level below $1 \%$ and above $99 \%$.

TABLE I. SUMMARY AND DEFINITION OF RESEARCH VARIABLE

\begin{tabular}{|c|c|c|c|}
\hline $\begin{array}{l}\text { Variable } \\
\text { Category }\end{array}$ & Variable Name & $\begin{array}{l}\text { Variable } \\
\text { Symbol }\end{array}$ & Calculation Method \\
\hline $\begin{array}{l}\text { Explained } \\
\text { variable }\end{array}$ & $\begin{array}{l}\text { Cost of equity } \\
\text { capital }\end{array}$ & $\mathrm{COE}$ & $\begin{array}{l}\text { Calculated with the PEG } \\
\text { model }\end{array}$ \\
\hline $\begin{array}{l}\text { Explanato } \\
\text { ry } \\
\text { variable }\end{array}$ & $\begin{array}{l}\text { Corporate social } \\
\text { responsibility } \\
\text { information } \\
\text { disclosure level }\end{array}$ & Score & Rankins CSR Score /10 \\
\hline \multirow{11}{*}{$\begin{array}{l}\text { Control } \\
\text { variable }\end{array}$} & $\begin{array}{l}\text { Scale of } \\
\text { company }\end{array}$ & Size & $\begin{array}{l}\text { The natural log of the total } \\
\text { assets at the end of the } \\
\text { period }\end{array}$ \\
\hline & Equity nature & State & $\begin{array}{l}\text { State-owned holding is } 1 \text {, } \\
\text { otherwise } 0\end{array}$ \\
\hline & $\begin{array}{l}\text { Shareholding } \\
\text { ratio of the } \\
\text { largest } \\
\text { shareholder }\end{array}$ & First & $\begin{array}{l}\text { The number of shares held } \\
\text { by the largest shareholder / } \\
\text { total number of shares of } \\
\text { the company }\end{array}$ \\
\hline & ROTFAM & Indeper & $\begin{array}{l}\text { The number of independent } \\
\text { directors / the number of } \\
\text { board members }\end{array}$ \\
\hline & $\begin{array}{l}\text { Sustainable } \\
\text { growth rate }\end{array}$ & $\begin{array}{l}\text { Sustainabl } \\
\text { e }\end{array}$ & $\begin{array}{l}\text { Return on net assets * } \\
\text { income retention rate / }(1- \\
\text { return on net assets * } \\
\text { income retention rate) }\end{array}$ \\
\hline & $\begin{array}{l}\text { Rate of return } \\
\text { on total assets }\end{array}$ & ROA & $\begin{array}{l}\text { Net profit / total assets } \\
\text { balance }\end{array}$ \\
\hline & $\begin{array}{l}\text { Asset-liability } \\
\text { ratio }\end{array}$ & Lev & Total liabilities/total assets \\
\hline & $\begin{array}{l}\text { Total asset } \\
\text { turnover }\end{array}$ & Turn & $\begin{array}{lcr}\text { Total } & \text { assets/ } & \text { ending } \\
\text { balance } & \text { of } & \text { operating } \\
\text { income } & & \\
\end{array}$ \\
\hline & $\begin{array}{l}\text { Operating } \\
\text { leverage }\end{array}$ & Orisk & $\begin{array}{l}\text { Non-current assets/total } \\
\text { assets }\end{array}$ \\
\hline & Stock turnover & Turnover & $\begin{array}{l}\text { Total number of shares } \\
\text { traded per day / total } \\
\text { number of shares } \\
\text { outstanding } \times 100 \%\end{array}$ \\
\hline & $\begin{array}{l}\text { The listed } \\
\text { number }\end{array}$ & Time & The listed number \\
\hline
\end{tabular}

\section{EMPIRICAL ANALYSIS}

\section{A. Descriptive Statistics}

According to "Table II", from the COE of the enterprise's equity capital cost, the maximum value is 0.367 , the minimum value is 0.0499 , and the mean is $0.105(0.101)$, indicating that the differences of sample company's equity capital cost are not large; among the sample companies, state-owned enterprises accounted for $60.3 \%$, indicating that state-owned enterprises disclose more social responsibility information; the maximum level of corporate responsibility information disclosure level is 8.795 , the minimum value is 1.7 , and the average value is 4.110 , indicating that the level of corporate social responsibility information disclosure is not high. In terms of the size of the controlling variable company, the shareholding ratio of the largest shareholder, the stock turnover rate and the listed number, the differences between different companies are also large. 
TABLE II. DESCRIPTIVE STATISTICS OF VARIABLES

\begin{tabular}{|l|l|l|l|l|l|}
\hline Variate & $\begin{array}{c}\text { Observed } \\
\text { Value }\end{array}$ & Minimum & Maximum & Mean & $\begin{array}{c}\text { Sandard } \\
\text { Deviation }\end{array}$ \\
\hline COE & 944 & 0.0499 & 0.367 & 0.105 & 0.0410 \\
\hline Score & 944 & 17.00 & 87.95 & 41.10 & 1.119 \\
\hline Size & 944 & 19.82 & 28.51 & 23.08 & 1.433 \\
\hline State & 944 & 0 & 1 & 0.603 & 0.489 \\
\hline First & 944 & 0.0339 & 0.8941 & 0.3877 & 16.44 \\
\hline Sustainable & 944 & -1.562 & 5.672 & 0.0560 & 0.169 \\
\hline ROA & 944 & -0.586 & 0.482 & 0.0380 & 0.0580 \\
\hline Lev & 944 & 0.00800 & 1.037 & 0.495 & 0.207 \\
\hline Turn & 944 & 0.00100 & 7.609 & 0.653 & 0.519 \\
\hline Orisk & 944 & 0 & 0.981 & 0.465 & 0.231 \\
\hline Turnover & 944 & 0.0290 & 32.03 & 5.303 & 3.955 \\
\hline Time & 944 & 4.100 & 26.90 & 15.39 & 5.786 \\
\hline
\end{tabular}

\section{B. Correlation Analysis}

In order to explain the correlation of variables in each model, and to test whether the selected variables have collinearity, Pearson correlation analysis is performed on the relevant variables in the model. The test results are shown in "Table III". The explanatory variable Score is negatively correlated with the cost of equity capital (COE). In addition, there are significant correlations between the three variables and the cost of equity capital (COE) in the selection of control variables.

TABLE III. CORRELATION ANALYSIS BETWEEN VARIABLES

\begin{tabular}{|c|c|c|c|c|c|c|c|c|}
\hline & COE & Score & Size & State & First & ROA & Turn & $\begin{array}{c}\text { Turno } \\
\text { ver }\end{array}$ \\
\hline $\mathrm{COE}$ & 1 & & & & & & & \\
\hline Score & $\begin{array}{l}- \\
0.030 \\
0 *\end{array}$ & 1 & & & & & & \\
\hline Size & $\begin{array}{l}0.185 \\
\text { *** }\end{array}$ & $\begin{array}{l}0.431 \\
\text { *** }\end{array}$ & 1 & & & & & \\
\hline State & $\begin{array}{l}- \\
0.069 \\
* * *\end{array}$ & $\begin{array}{l}0.183 \\
\text { *** }\end{array}$ & $\begin{array}{l}0.336 \\
* * *\end{array}$ & 1 & & & & \\
\hline First & $\begin{array}{l}- \\
0.028 \\
0 \\
\end{array}$ & $\begin{array}{l}0.168 \\
* * *\end{array}$ & $\begin{array}{l}0.300 \\
* * *\end{array}$ & $\begin{array}{l}0.272 \\
* * *\end{array}$ & 1 & & & \\
\hline ROA & $\begin{array}{l}0.026 \\
0\end{array}$ & $\begin{array}{l}0.038 \\
0\end{array}$ & $\begin{array}{l}- \\
0.059 \\
* *\end{array}$ & $\begin{array}{l}- \\
0.140 \\
* * *\end{array}$ & $\begin{array}{l}0.031 \\
0\end{array}$ & 1 & & \\
\hline Turn & $\begin{array}{l}- \\
0.033 \\
0\end{array}$ & $\begin{array}{l}0.106 \\
\text { *** }\end{array}$ & $\begin{array}{l}- \\
0.005 \\
00\end{array}$ & $\begin{array}{l}0.007 \\
00\end{array}$ & $\begin{array}{l}0.059 \\
* *\end{array}$ & $\begin{array}{l}0.085 \\
\text { *** }\end{array}$ & 1 & \\
\hline $\begin{array}{l}\text { Turno } \\
\text { ver }\end{array}$ & $\begin{array}{l}- \\
0.199 \\
* * *\end{array}$ & $\begin{array}{l}- \\
0.169 \\
* * *\end{array}$ & $\begin{array}{l}- \\
0.320 \\
* * *\end{array}$ & $\begin{array}{l}- \\
0.192 \\
* * *\end{array}$ & $\begin{array}{l}- \\
0.279 \\
* * *\end{array}$ & $\begin{array}{l}- \\
0.141 \\
* * *\end{array}$ & $\begin{array}{l}- \\
0.084 \\
* * *\end{array}$ & 1 \\
\hline
\end{tabular}

\section{Regression Analysis Results}

The regression results are shown in "Table IV": The score of social responsibility information disclosure level is significant at the level of $10 \%$, and the equity capital cost $\mathrm{COE}$ and the explanatory variable Score are significantly negatively correlated, that is, the higher the level of corporate social responsibility information disclosure, the lower the equity capital cost is. At the same time, the scale of the company and the cost of equity capital are significantly positively correlated at the $1 \%$ level; the nature of equity and the cost of equity capital are significantly negatively correlated at the $1 \%$ level; the shareholding ratio of the largest shareholder is significantly negatively correlated with the cost of equity capital at the $1 \%$ level. The total asset turnover rate and stock turnover rate are the same as expected, but not significant. At the same time, the R-square value is 0.1021 , which indicates that the selected independent variables and control variables have a certain interpretation effect on the change of the cost of equity capital.

TABLE IV. REGRESSION RESUlTS OF EQUITY CAPITAL COST EFFECTS OF MEDIA DISCLOSURE OF SOCIAL RESPONSIBILITY INFORMATION DISCLOSURE

\begin{tabular}{|l|l|l|l|ll|}
\hline Variate & Coefficient & SE & Significance & \multicolumn{1}{|c|}{ Results } \\
\hline Score & -0.00225 & 0.083 & $*$ & $\begin{array}{l}\text { Significant on } \\
\text { level 10\% }\end{array}$ & $\begin{array}{l}\text { Significant on } \\
\text { level 1\% }\end{array}$ \\
\hline Size & 0.00695 & 0.000 & $* * *$ & $\begin{array}{l}\text { Significant on } \\
\text { level 1\% }\end{array}$ \\
\hline State & -0.0133 & 0.000 & $* * *$ & $\begin{array}{l}\text { Significant on } \\
\text { level 5\% }\end{array}$ \\
\hline First & -0.000207 & 0.022 & $* *$ & Not significant \\
\hline ROA & 0.0324 & 0.213 & - & Not significant \\
\hline Turn & 0.00435 & 0.158 & - & Not significant \\
\hline Turnover & -0.000213 & 0.608 & - & Not significant \\
\hline Constant & -0.0382 & 0.129 & - & \\
\hline Year & Control & & \\
\hline R2 & 0.1021 & & & \\
\hline $\begin{array}{l}\text { Observed } \\
\text { value }\end{array}$ & 944 & & & \\
\hline
\end{tabular}

\section{Robustness Test}

To demonstrate the robustness of the regression results, refer to Kuo and Chen (2013), Abbott and Monsen (1979), Dhaliwal et al. (2012), Ni Hengwang (2015), etc., using report pages to measure the level of corporate social responsibility information disclosure[23] [24] [25], the results are shown in "Table V". The level of social responsibility information disclosure is still significantly negatively correlated with the cost of equity capital COE, that is, the higher the level of corporate social responsibility information disclosure, the lower the cost of corporate equity capital. Therefore, after replacing the explanatory variables with the number of social responsibility report pages, the regression results of the model are basically consistent with the previous ones, indicating that the model design is more reasonable, and the previous results are robust.

TABLE V. EQUITy CAPITAL COST EFFECT RoBUSTNESS TEST OF SOCIAL RESPONSIBILITY INFORMATION DISCLOSURE

\begin{tabular}{|l|l|c|l|l|}
\hline Variate & Coefficient & SE & Significance & \multicolumn{1}{|c|}{ Results } \\
\hline Score & -0.00101 & 0.093 & $*$ & $\begin{array}{l}\text { Significant on level } \\
10 \%\end{array}$ \\
\hline Size & 0.00685 & 0.000 & $* * *$ & Significant on level 1\% \\
\hline State & -0.0133 & 0.000 & $* * *$ & Significant on level 1\% \\
\hline First & -0.000203 & 0.023 & $* *$ & Significant on level 5\% \\
\hline ROA & 0.0281 & 0.272 & - & Not significant \\
\hline Turn & 0.00388 & 0.204 & - & Not significant \\
\hline Turnover & -0.000226 & 0.580 & - & Not significant \\
\hline Constant & -0.0420 & 0.104 & - & Not significant \\
\hline Year & Control & & & \\
\hline R2 & 0.099 & \multicolumn{5}{|l}{} \\
\hline $\begin{array}{l}\text { Observed } \\
\text { value }\end{array}$ & 944 &
\end{tabular}

Notes: *** $\mathrm{p}<0.01, * * \mathrm{p}<0.05, * \mathrm{p}<0.1$ 


\section{CONCLUSION}

Based on the theory of signal transmission and the theory of legitimacy, combined with the current practice in China, this paper analyzes the logical mechanism of social responsibility information disclosure affecting the cost of equity capital of enterprises, and uses the data of listed companies to conduct empirical tests, and draws the following conclusions: corporate social responsibility information disclosure has a significant negative impact on the cost of equity capital. This shows that adequate information disclosure can improve the transparency of capital market information, effectively reduce the cost of information collection and processing, and thus improve the liquidity of stocks. At the same time, by meeting the information needs of investors, it helps to reduce information uncertainty, improve forecast accuracy, and reduce future risk expectations, thereby reducing the cost of equity capital due to risk premium.

However, at present, China's corporate social responsibility information disclosure is generally low, and the enthusiasm of disclosure is low, and most of them are mandatory disclosures that cater to national laws. At the same time, China has not yet established a sound social responsibility information disclosure system and system norms. Therefore, it is necessary to work together to improve the disclosure status, improve the disclosure level, and give full play to the value of corporate social responsibility information. From the perspective of the government, we should start from the two aspects of sound laws and regulations and strengthen government supervision to build and improve the disclosure system. From the perspective of enterprises, social responsibility should be included in the decision-making framework. At the same time, relevant laws should be observed, and external communication should be actively carried out to fully recognize the value that social responsibility information disclosure can bring.

\section{REFERENCES}

[1] Anderson J C, Frankle A W. Voluntary Social Reporting: An Iso-Beta Portfolio Analysis[J]. Accounting Review, 1980, 55(3):467-479.

[2] Cornell , Shapiro.Corporate social responsibility and financial performance. Financial Management, 1987,16: 5 -14

[3] Robinson M J, Kleffner A, Bertels S. The Value of a Reputation for Corporate Social Responsibility: Empirical Evidence[J]. 2013.

[4] Zeng Ying, Lu Zhengfei. Quality of Information Disclosure and Equity Financing Costs[J]. Economic Research, 2006(2): 69-79.

[5] Yang Qiulin, Dai Jinyun. Research on the Correlation between Social Responsibility Information Disclosure and Equity Capital CostsEvidence from Social Responsibility Information Disclosure of ChinaShenzhen Listed Companies[C]// Proceedings of the 2011 Annual Conference of the Environmental Accounting Professional Committee of the Chinese Accounting Association. 2011.

[6] Li Shu, Zhao Ying, Tong Jing. Does the social responsibility report reduce the cost of corporate equity capital?__Evidence from Chinese capital market[J]. Accounting Research, 2013(9): 64-70.

[7] Li Huiyun, Liu Di. Marketization Process, Voluntary Information Disclosure and Equity Capital Costs[J]. Accounting Research, 2016(1): 71-78.

[8] Huang Jianyuan, Jin Yue. Research on the Impact of Corporate Social Responsibility on the Cost of Equity Capital-Based on the
Perspective of Corporate Social Responsibility Reporting and Assurance[J]. Industrial Economics Research, 2016(2): 87-95.

[9] Richardson A J, Welker M. Social disclosure, financial disclosure and the cost of equity capital[J]. Accounting Organizations \& Society, 2001, 26(7):597-616

[10] Meng Xiaojun, Xiao Zuoping, Qu Jiali. The Interaction between Corporate Social Responsibility Information Disclosure and Capital Cost_-An Analysis Framework Based on Information Asymmetry[J]. Accounting Research, 2010(9): 25-29.

[11] Myers S C, Majluf N S. Corporate financing and investment decisions when firms have information that investors do not have $\sum_{3}[\mathrm{~J}]$. Social Science Electronic Publishing, 2001, 13(2):187-221.

[12] Copeland T E, Dan G. Information Effects on the Bid - Ask Spread[J] Journal of Finance, 1983, 38(5):1457-1469.

[13] Yoshikawa T, Phan P H. Alternative Corporate Governance Systems in Japanese Firms: Implications for a Shift to Stockholder-Centered Corporate Governance[J]. Asia Pacific Journal of Management, 2001, 18(2):183-205

[14] Suchman M C. Managing Legitimacy: Strategic and Institutional Approaches[J]. Academy of Management Review, 1995, 20(3):571-610.

[15] Clarke J, Gibson-Sweet M. The use of corporate social disclosures in the management of reputation and legitimacy: a cross sectoral analysis of UK Top 100 Companies[J]. Business Ethics A European Review, 2010, 8(1):5-13.

[16] Deegan C, Rankin M. THE ENVIRONMENTAL REPORTING EXPECTATIONS GAP: AUSTRALIAN EVIDENCE [J]. British Accounting Review, 1999, 31(3):313-346.

[17] Mathews M R. Social and environmental accounting: A practical demonstration of ethical concern?[J]. Journal of Business Ethics, 1995, 14(8):663-671.

[18] James Guthrie, Lee D. Parker. Corporate Social Reporting: A Rebuttal of Legitimacy Theory[J]. Accounting \& Business Research, 1989, 19(76):343-352.

[19] Dowling J, Pfeffer J. Organizational Legitimacy: Social Values and Organizational Behavior[J]. Pacific Sociological Review, 1975, 18(1):122-136.

[20] Chen Yuqing, Ma Lili. An Empirical Analysis of the Market Response of Social Responsibility Accounting Information in China's Listed Companies[J]. Accounting Research, 2005(11): 76-81.

[21] Tang Yali, Chen Zili, Liu Xing, et al. Empirical Study on Environmental Information Disclosure Status and Influencing Factors of China's Listed Companies[J]. Management World, 2006(1): 158-159.

[22] Mao Xinshu, Ye Kangtao, Zhang Di. Measurement and Evaluation of Equity Capital Cost of Listed Companies_-Based on Empirical Test of China's Securities Market[J]. Accounting Research, 2012(11):12-22.

[23] Kuo L, Chen Y J. Is environmental disclosure an effective strategy on establishment of environmental legitimacy for organization?[J]. Management Decision, 2013, 51(7):1462-1487.

[24] Dan S D, Radhakrishnan S, Tsang A, et al. Nonfinancial Disclosure and Analyst Forecast Accuracy: International Evidence on Corporate Social Responsibility Disclosure[J]. Social \& Environmental Accountability Journal, 2013, 33(3):180-181.

[25] Ni Hengwang, Li Changqing, Wei Zhihua. Media attention, corporate voluntary social responsibility information disclosure and financing constraints[J]. Journal of Shanxi University of Finance and Economics, 2015, 37(11): 77-88 